\title{
- PEOPL
}

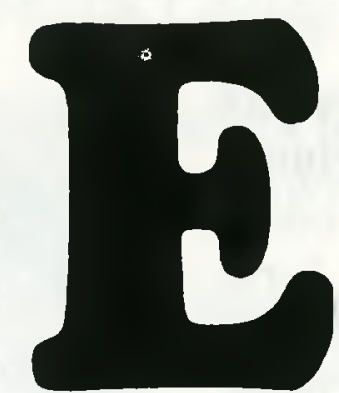

\section{Profiles}

JOHN W. BERRY, systems development librarian at Northern Illinois University, has been appointed executive director of ALA's Library Administration and Management Association, effective April 1. He succeeds Roger Parent, who recently was named deputy executive director of the American Library Association.

Berry has been at NIU since 1980 with his appointment as reference librarian, later becoming acting assistant director for public services in 1983 and systems de-

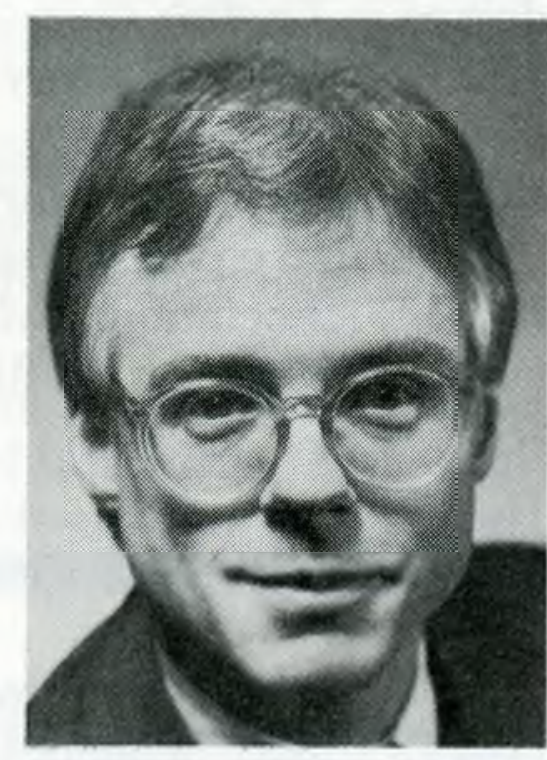

John W. Berry velopment librarian in 1984. Prior to that he served as public services coordinator at Elmira College from 1974 to 1980, and head of Microforms Services at Indiana University from 1973 to 1974.

A side interest in photography has allowed Berry to teach fine art photography and history of pho-

\section{FID calls for papers}

"Information, Communications and Technology Transfer" will be the theme of the $43 \mathrm{~d}$ Conference and Congress of the International Federation for Documentation (FID) in Montreal, Quebec, September 14-18, 1986. Proposed topics include new techniques for information handling and information transfer, advances in communications systems, advances in computer systems, electronic publishing, electronic document delivery systems, and all aspects of technology transfer.

The conference languages will be English and French; original papers in either language are requested. Authors are asked to submit six copies of a summary of their proposed paper to the conference chair by June 30, 1985: Mr. E.V. Smith, Director, CISTI, National Research Council of Canada, Ottawa, Ontario, Canada KlA 0S2. tography courses at Elmira College, and to lecture to art classes at Northern Illinois. He holds a bachelor's degree in political science (1969), a master's in social studies (1971), and an MLS (1974) from Indiana University.

A member of ALA's Committee on Organization since 1984, Berry has also served as chair of the LAMA Subcommittee on JMRT (Junior Members Round Table) Relations and the Subcommittee on the LAMA Booth. He has been an ACRL member since 1974.

EDWARD D. GARTEN has been appointed director of university libraries at the University of Dayton, effective July 1, 1985.

Since 1980 Garten has been director of libraries at Tennessee Tech University; prior to that he was director of the $\mathrm{Li}$ brary and Learning Resources Center at Northern State College, Aberdeen, South Dakota.

Garten holds a Ph.D. in higher education administration from the University of Toledo, an MLS from Kent State

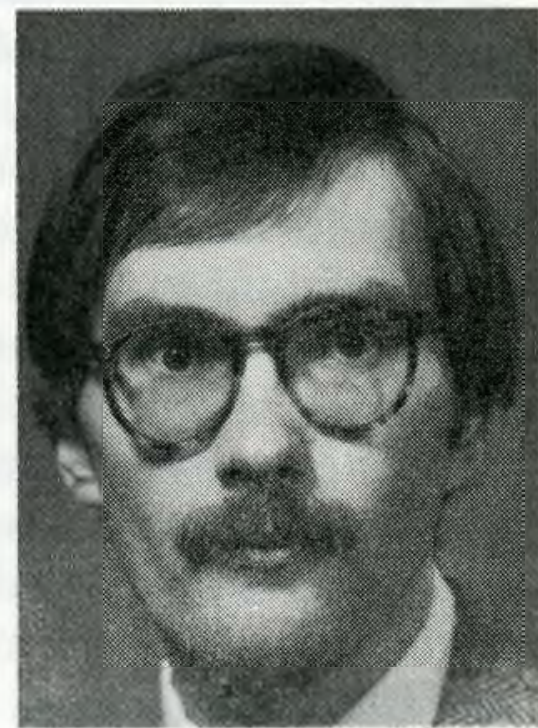

Edward D. Garten University, and master's degrees from the Methodist Theological School. He has done post-doctoral study in Great Britain and the Soviet Union.

A member of the Board of Directors of ALA's Library Administration and Management Association, Garten also serves as editor of the LAMA Newsletter. He has done editorial work with $L i$ brary Hi Tech and serves on the Editorial Board of Personnel Administrator. $\mathrm{He}$ is credentialed as a personnel specialist by the American Society for Personnel Administration and has been engaged in a wide range of consulting activities in the personnel and human relations fields.

From 1983 to 1984 he served as chair of the State Board of Regents (Tennessee) Library Directors' Council and in June will complete a term as chair of the State Board of Regents Media Advisory Council. 
IMOGENE I. BOOK has been named director of the Learning Resource Center at Denmark Technical College, South Carolina. She came to Denmark from Rend Lake College, Ina, Illinois, where she served as librarian.

Book recently completed a four-year term as a member of the ACRL Board of Directors. She has also served as chair of ACRL's Community and Junior College Libraries Section, past president of the Illinois Association of College and Research Libraries, and secretary of the Illinois Associa-

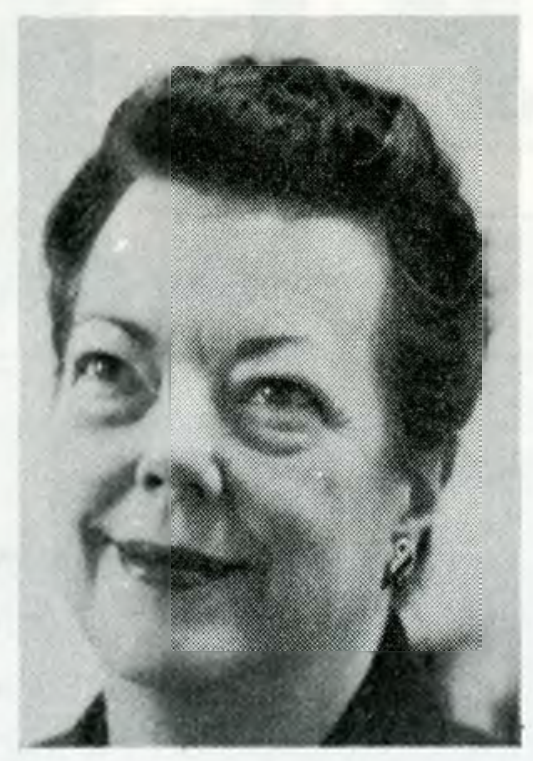

Imogene Book tion of School Librarians. Book is currently chair of the CJCLS Planning and Procedures Committee and serves on the CJCLS Membership/Communications Committee.

Book holds an MLS and a certificate of advanced study in librarianship from the University of Illinois and a bachelor's degree in education from Southern Illinois University. She is currently a doctoral student in educational media at Southern Illinois University.

JERRY WAyne STEPHENS has been named librarian and director of the Mervyn Stone Library at the University of Alabama, Birmingham. He was previously assistant director for administrative services, assistant to the director, and accountant at $\mathrm{UAB}$.

Stephens holds an MLS and a doctorate in administration and higher education from the University of Alabama in Tuscaloosa, and a master's degree in business administration and a bachelor of science degree from Bir-

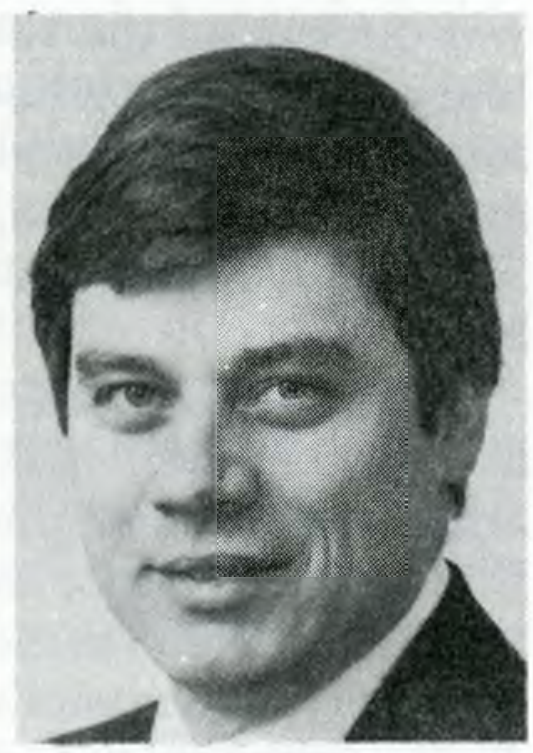

Jerry Wayne Stephens mingham. He has also been a part-time member of the School of Business

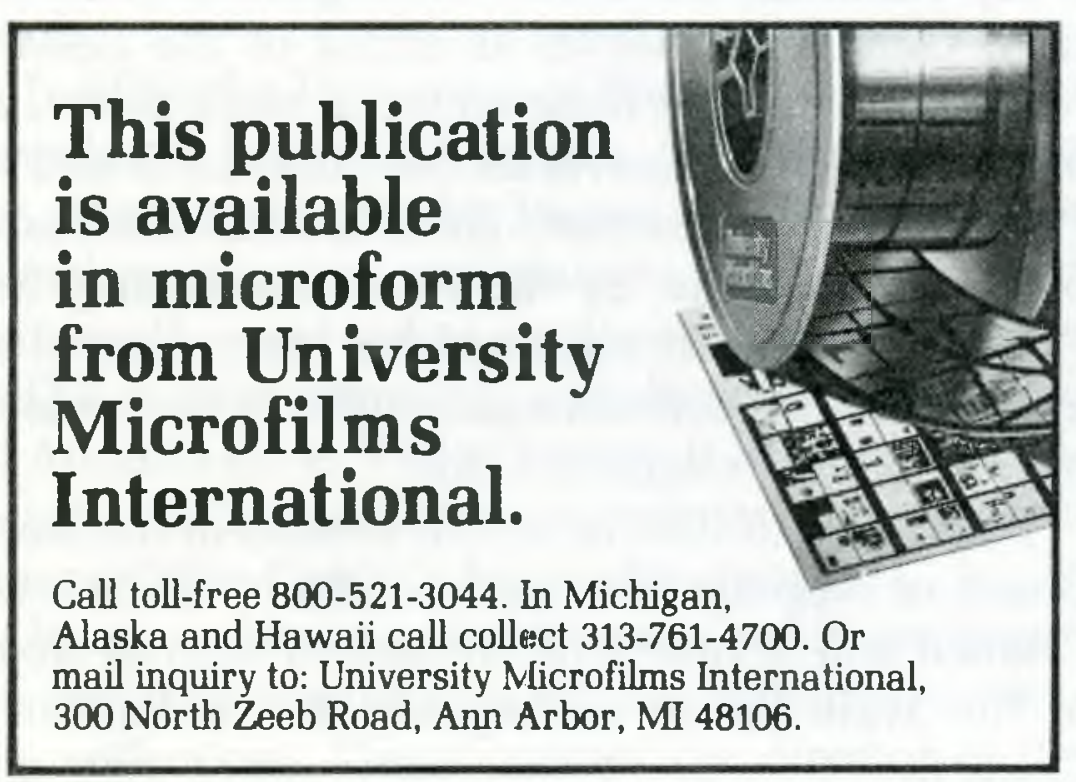

faculty at UAB, and has served on a variety of committees and task forces in the University College.

LERoy STROHL has been appointed librarian of Mary Washington College, Fredericksburg, Virginia.

He comes to this position from Emory and Henry College where he has served as head librarian since 1974. Prior to that he was technical services librarian at Roger Williams College (1972-1974) and acquisitions assistant at Kentucky State University (1970-1972). He holds an MLS and a master's degree in English literature from the University

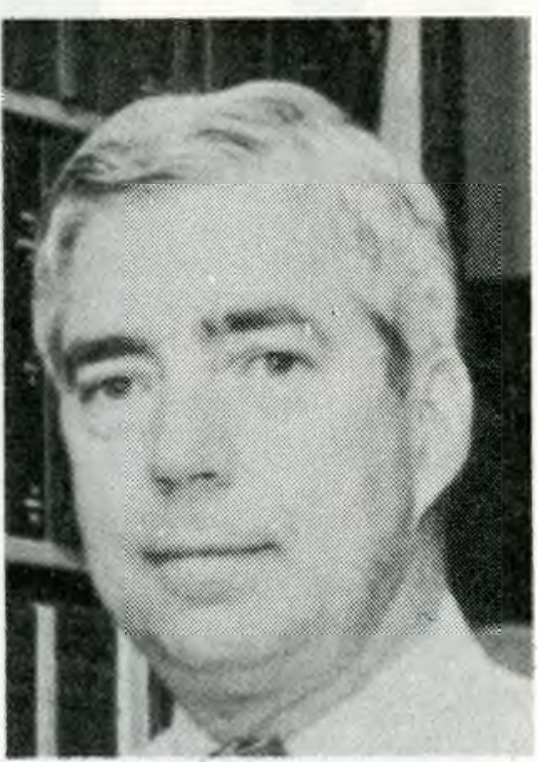

LeRoy Strohl of Kentucky and a bachelor's degree from Hanover College.

Strohl has chaired several sections in the Virginia Library Association, including its College and University Section, an ACRL chapter.

\section{People in the news}

Charles H. Davis, dean of the University of Illinois Graduate School of Library and Information Science, will step down from that position to return to teaching and research, effective August 21, 1985.

Davis was appointed dean in 1979, succeeding Herbert Goldhor, who bore the title of director. He holds three degrees from Indiana University, a bachelor's in chemistry and physics, as well as an MLS and a doctorate in library and information science. He hasalso studied toxicology at Indi-

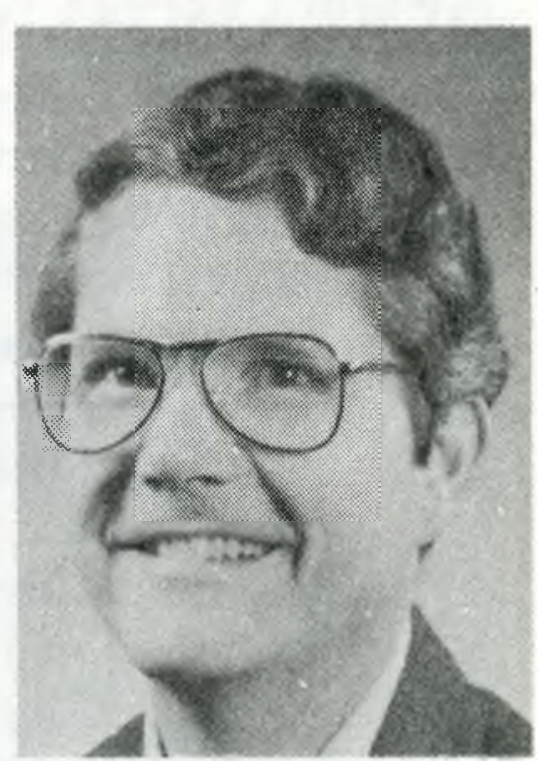

Charles H. Davis ana and chemistry at the University of Munich, West Germany.

Before coming to Illinois, Davis was dean of the Faculty of Library Science at the University of Alberta. He also served on the faculty of Indiana and Drexel Universities and University of Michigan.

The author of several books on information retrieval and programming, Davis served as president of the American Society for Information Science in 1982-1983 and currently is a consultant to the National Science Council of Taiwan. In 1982 he received the Louise Maxwell Award given by the alumni association of the Indiana University School of Library and Information Science. 


\section{Appointments}

(Appointment notices are taken from library newsletters, letters from personnel offices and appointees, and other sources. To ensure that your appointment appears, write to the Editor, ACRL, 50 E. Huron St., Chicago, IL 60611-2795.)

GoRDON ANDERSON has been appointed head of the Slavic Department at the University of Kansas Libraries, Lawrence.

NANCY L. BAKER has been appointed associate director for public services at the University of Washington, Seattle.

Everett Wayne Barnes has been appointed general reference/documents librarian at the University of Missouri, Columbia.

Denise M. BEaUbien has been appointed assistant reference librarian at the Engineering and Physics Library, University of Florida, Gainesville.

FLORENCE BLAKELY, assistant university librarian for collection development at Duke University, Durham, North Carolina, has been named acting university librarian.

Gilliam C. Boal has been appointed book conservator at the University of California, Berkeley.

ANNE BOCK is the new circulation librarian at Hastings Law Library, University of California, San Francisco.

LORI BRONARS has been appointed science reference librarian at Texas A\&M University, College Station.

BEN Burrows has been appointed support services librarian at Northwestern University, Evanston, Illinois.

Iris Caldwell has been appointed reference/documents librarian at Nova Law Library, Fort Lauderdale.

Walter Champion has been appointed director of the Law Library at Texas Southern University, Houston.

Marie L. Clark has been appointed head of the Public Documents and Maps Department, Duke University Library, Durham, North Carolina.

Rosalind CoOPER has been appointed reader services librarian in the Science Library at Brandeis University, Waltham, Massachusetts.

JAMES F. COREY has been appointed director of the Florida Center for Library Automation, Gainesville.

GaIL DALY has been named assistant director for technical services at the University of Minnesota Law Library, Minneapolis.

LESLIE DONNELLY has been appointed general reference librarian at Drexel University, Philadelphia.

JACKIE M. Dooley has been appointed special collections librarian at the University of California, San Diego.

CECILE Doty is now catalog librarian at the University of Kansas Medical Center, Kansas City.

Catherine A. Eckman is now reference librar- ian at the University of South Carolina, Columbia.

Carol Elliott is now reference librarian at the University of Arizona College of Law Library, Tucson.

ROCHELle Berger ElsteIn has been appointed art bibliographer at Northwestern University, Evanston.

BRUCE EMERTON has been appointed assistant reference librarian at the University of Florida Education Library, Gainesville.

ElizabeTh M. Evans has been promoted to computer services/referenmce librarian at the New York University School of Law.

JOHN MARK FARRELL is now law reference librarian at the University of Bridgeport Law Library, Connecticut.

KaARINA FLINT has been appointed head of the Interlibrary Services Division at the University of California, Los Angeles.

Arturo A. Flores has been named reference librarian at the University of California, Berkeley Law Library.

William C. Fray is now serials librarian at the University of Bridgeport Law Library, Connecticut.

RICHARD FrIEDER has been appointed conservation officer at Northwestern University, Evanston.

LOLLY GaSaWAY has been named law librarian at the University of North Carolina, Chapel Hill.

Lia HemphILl has been appointed acquisitions/serials librarian at Nova University Law Library, Fort Lauderdale, Florida.

Frank P. Houdek has been named director of the Law Library at Southern Illinois University, Carbondale.

JAMES A. JACOBS has been appointed reference librarian and bibliographer for the social sciences at the University of California, San Diego.

BRENDA L. JoHNSON has been appointed assistant to the director at the University of Michigan Library, Ann Arbor.

Patrick Kellough has been appointed cataloger for special collections at Texas A\&M University, College Station.

CoRnelia S. KING has been appointed rare book cataloger for the Rare Book Department of the Free Library of Philadelphia.

PEARL T. KING is the new reference librarian at the California Western School of Law Library, San Diego.

GaY Toltl Kinman has been appointed associate law librarian at Western State University College of Law Library, Fullerton, California.

RichaRd L. KorT is the new cataloger for the Roman Jakobson Collection on Linguistics at the Massachusetts Institute of Technology, Cambridge.

JOAN KunSELMAN has been appointed fine arts librarian at the University of California, Los Angeles.

Deanna LynN Lewis is now a cataloger at the University of South Carolina, Columbia.

MAY HARN LIU is a new cataloger at the Univer- 
sity of South Carolina, Columbia.

KaREN MATtHEWs has been appointed cataloger at Emporia State University, Kansas.

JIM MEYER has been appointed NOTIS marketing librarian at Northwestern University, Evanston, Illinois.

DAHRL E. MOORE has been appointed interlibrary loan librarian at Florida Atlantic University, Boca Raton.

Mary Moore has been appointed education librarian at Texas A\&M University, College Station.

JoYCE NEvins has been appointed public services librarian at the Science-Engineering Library, Northwestern University, Evanston, Illinois.

William Osuga is now acting head of the Oriental Library at the University of California, Los Angeles.

Pamela B. Pasak is the assistant humanities reference librarian at the University of Florida, Gainesville.

Orest Pelech has been appointed Slavic/Western European bibliographer at Duke University, Durham, North Carolina.

JANET Pinkowitz has been appointed reference librarian for subscription services at the Columbia University Law Library, New York.

DARRYL PODOLL is now library director at Valley City State College, North Dakota.

David Rabasca is now reference librarian in the Anglo-American Law Division of the Library of Congress.

GRETCHEN REDFIELD has joined the staff of the Bibliographical Center for Research, Denver, as manager of Bibliographic Systems and Services.

MARTHA RICHARDSON has been appointed manager of customer services at Blackwell Library Systems, Great Neck, New York.

LYNN ROUNDTREE has been named curator of the Russell Long Collection at Louisiana State Univeristy, Baton Rouge.

ANGEla Sabina has been appointed microforms librarian at Florida Atlantic University, Boca Raton.

ANN SCHULTIS is now circulation librarian at the University of Texas, El Paso.

DoNNA SERAFIN has been appointed preservation officer at the State University of New York at Buffalo.

ANDREW D. SHROYER has been appointed serials acquisitions librarian at the University of California, Santa Barbara.

ALLISON Mook SLEEMAN has been appointed catalog librarian at Boston College, Chestnut Hill, Massachusetts.

Susan Swords STEFFEN has been appointed extended campus services reference librarian at Northwestern University, Evanston, Illinois.

JU-Yen TENG has been appointed assistant East Asian librarian at the University of Kansas, Lawrence.

ARTURo ToRres has been appointed reference librarian at the University of Arizona, Tucson.
ELIZABETh B. Wagner is a new reference librarian at Duke University, Durham, North Carolina.

Paula M. Walker has been appointed assistant director of libraries for undergraduate library services at the Odegaard Library, University of Washington, Seattle.

KenNeTH WaLter has been named librarian at Southern Connecticut State University, New Haven.

LoIS WARD has been named library director at Urbana University, Ohio.

JEANIE WELCH has been appointed head of reference at Lamar University, Beaumont, Texas.

KAREN WITTENBORg has been appointed assistant university librarian for collection development at the University of California, Los Angeles.

Thomas A. Woxland has been named assistant director for public services at the University of Minnesota Law Library, Minneapolis.

\section{Retirements}

RICHARD BERNER, university archivist and head of the University Archives and Manuscripts Division at the University of Washington, Seattle, retired on January 1 after 27 years with the library.

Cynthia Neal, chief of library services at the Providence Public Library, retired on February 12 after 28 years of service.

Mrron M. Weinstein, head of the Hebraic Section in the Library of Congress African and Middle Eastern Division, retired on November 30 almost 31 years of Federal service, including 29 years with LC.

MARJORIE WHEELER, head of reference at Lamar University Library, Beaumont, Texas, retired on January 31 after 16 years of service. Before coming to Lamar in 1969 she had been associated with the University of Texas at Arlington and the Graduate Research Center of the Southwest (now the University of Texas at Dallas). Her honors include a Merit Award from the Lamar University Board of Regents in 1982 and an award from Sigma Xi in 1983 in recognition of her outstanding work as a science and technology librarian.

\section{Deaths}

BEaTrice BaKer HaAn, emeritus professor of librarianship at Central Washington University, Ellensburg, died on February 3. She had been on the library faculty from 1951 until her retirement in 1969.

Mayellen LoPresti, librarian of the Harrye B. Lyons Design Library at North Carolina State University since 1977, died on January 30 . She had also been on the staff of the Georgia Institute of Technology, the Atlanta public Library, and the Nashville Public Library.

Amy Peterson, head of documents and research at the University of Wisconsin-Whitewater for more than 20 years, died on December 15. 


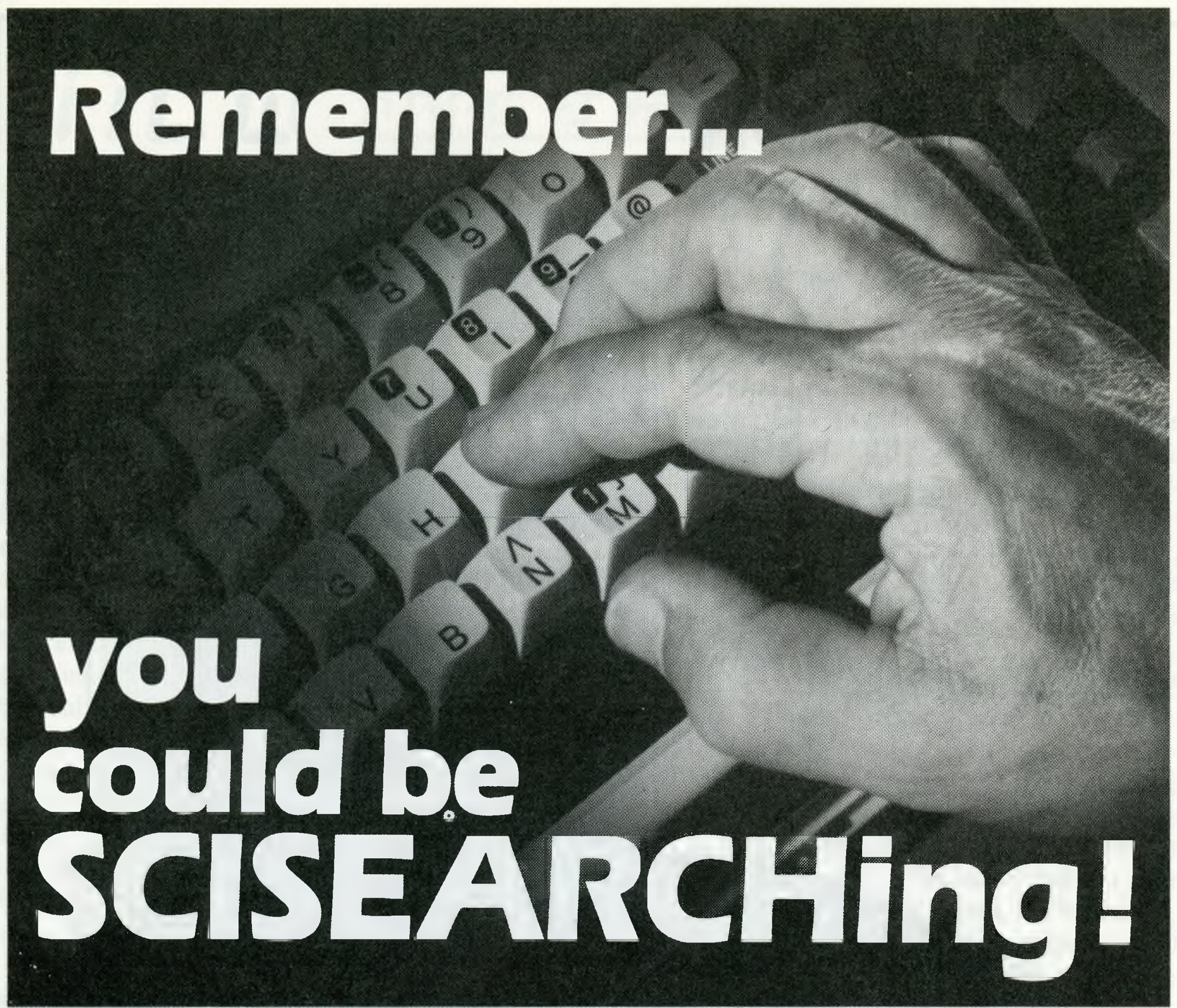

You trust SCISEARCH ${ }^{\circledR}$ to help you do fast, precise searches of the scientific literature. And SCISEARCH on DIALOG ${ }^{\circledR}$ is an active, growing file you can continue to depend on ... for thorough coverage of the worldwide scientific literature ... for biweekly updates that guarantee maximum currency ... and for ISI's unique cited reference searching. For more information about SCISEARCH on DIALOG, write us at the address below, or call us toll-free 800-523-1850. In Pennsylvania, call collect 215-386-0100, ext. 1371.

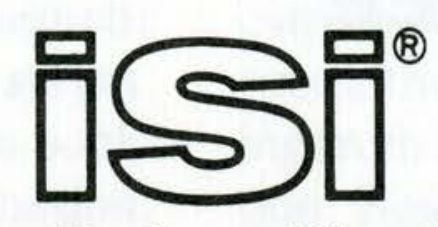

Institute for Scientific Information ${ }^{\circledR}$

Customer Services Department, 3501 Market Street, Philadelphia, PA 19104 U.S.A.

Telephone: (215)386-0100, ext. 1371, Cable: SCINFO, Telex: 84-5305

European Office: 132 High Street, Uxbridge, Middlesex UB8 1DP, United Kingdom

Telephone: 44-895-70016, Telex: 933693 UKISI 


\section{ACQUISITION PERSPECTIVES}

1. ANY BOOK IN PRINT .

means delivery to your library of all available books from any publisher or distributor in the U.S. or Canada. There is no list of publishers you must check ... WE DELIVER THEM ALL ... including trade, scientific/technical, text, university presses, paperbacks, associations, small presses, Canadian, and software.

Send us your direct orders and experience the "added value" received when using Book House.

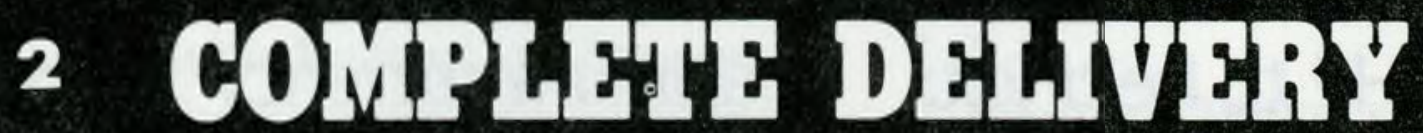

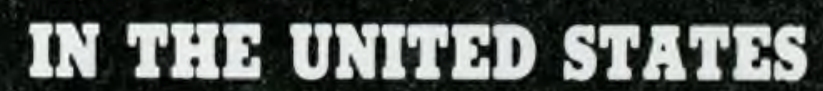
AND CANIDE

BOOK HOUSE
All BOOK it PRitis
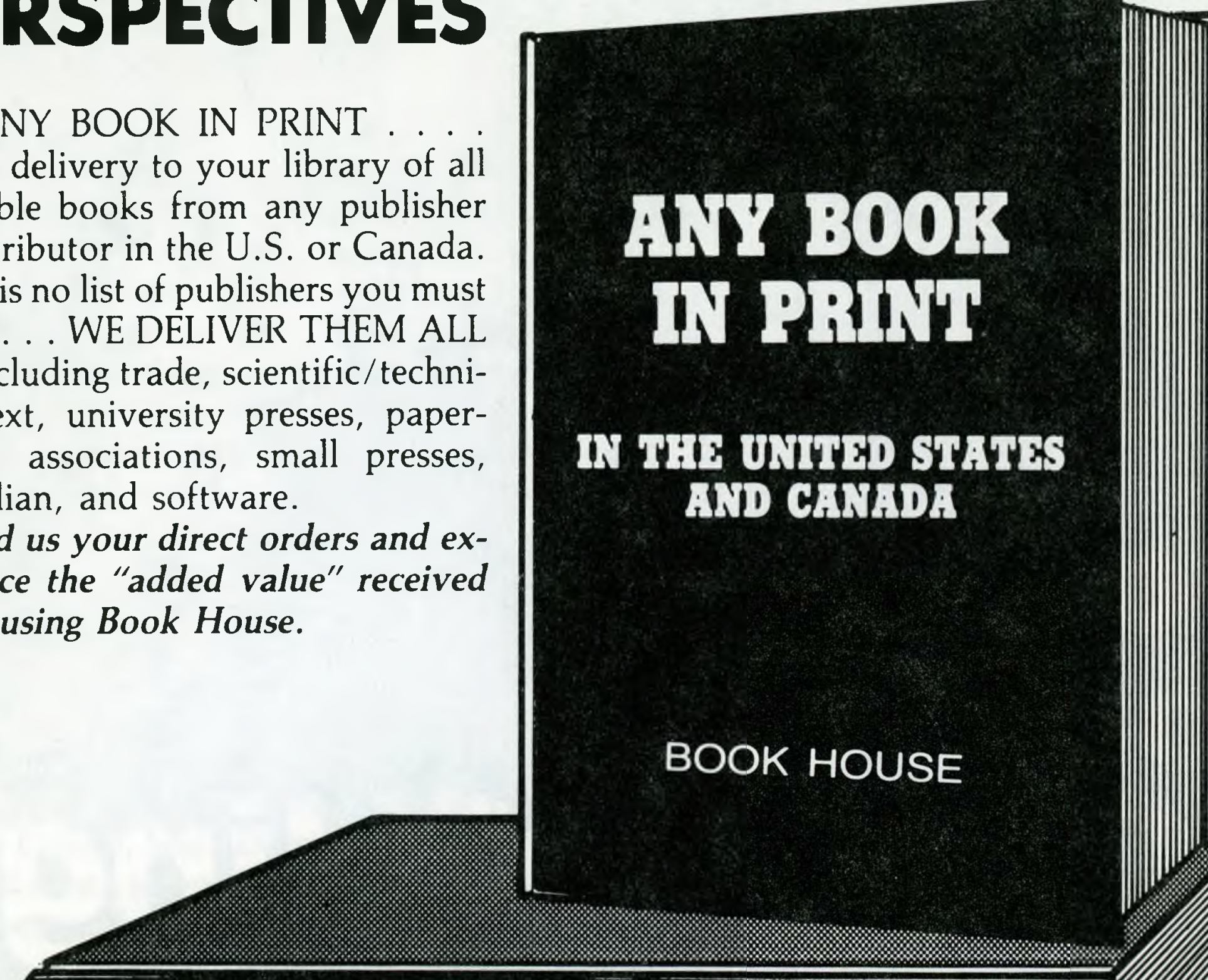

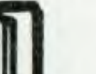

